\title{
急勾配河川におけるCRD法の適用性 ON THE APPLICABILITY OF CRD SCHEMES IN STEEP GRADIENT RIVER
}

\author{
堀江克也 1 ・森明巨 2 -平井康幸 3 ・西本直史 4 \\ Katsuya HORIE, Akio MORI, Yasuyuki HIRAI, and Naoshi NISHIMOTO \\ 1正会員 工修 いであ株式会社 水圈事業本部河川部（テ154-8585 東京都世田谷区駒沢3-15-1） \\ 2正会員 工博 いであ株式会社 水圈事業本部河川部（ $\bar{\top} 060-0062$ 北海道札幌市中央区南二条西9-1-2） \\ 3 正会員 寒地土木研究所 寒地河川チーム（テ062-8602 北海道札幌市豊平区平岸1条3丁目1-34） \\ 4正会員 博（工） いであ株式会社 水圈事業本部（テ154-8585 東京都世田谷区駒沢3-15-1）
}

Stream flows with steep gradient bed form complicating flow configurations, where super-critical and sub-critical flows co-exist. Computing numerically such flows are the key to successful river management. Contour-integral-based residual distribution, $\mathrm{CRD}$, schemes are one of the numerical computation to simulate the flow with shock waves. In the last fiscal year, the Authors applied the CRD schemes to one dimension and two dimensions of the open channel flow, and showed validity as compared with the experiment-with-a-model result or the theoretical value. However, in the paper, application has not carried out the CRD schemes to a natural river. In this paper, the CRD schemes are applied for the Toyohira River of a steep slope municipal river, and the applicability in a natural river is shown.

Key Words : numerical computation, contour-integral-based residual distribution, steep gradient river, compound river, shock capturing

\section{1. はじめに}

急勾配河川や河川構造物周辺等では常流・射流混在流 が発生するが，このような流れ場の水理量（水位，流向， 流速等）の精度よい解析は, 河川整備や河川管理等の検 討において重要である．例えば，堤防及び低水護岸の設 計に用いる代表流速 $V_{0}$ は，マニングの平均流速公式で 算定した平均流速に補正係数を乗じて算定する方法が一 般的である ${ }^{1}$ が，堰や床止め等の横断構造物周辺や低水 路平面形状が大きく変化する場では $V_{0}$ の適切な算定が 困難となる．このような場では精度の良い数值計算が有 用となる.

常流・射流混在流の計算はMacCormack法2)、CIP法3), Residual Distribution (RD) schemes ${ }^{4) 50}$ など現在までに多く の数值モデルが提案されているが，その一つとしてCRD 法》がある. CRD法は不連続解を持つ流れの多次元解析 法として開発され，MacCormack法のように陽的に人工 粘性を加える必要がない，また，RD法のように複雑な 線形化を必要とせず，単純平均で充分で，二次元河床変 動解析への適用が容易である. さらに, 平面二次元計算 では有限要素法のように非構造の三角形格子を用いるの で複雑な地形の扱いが容易である。一つの計算要素ごと に独立して計算するためベクトル化も簡単である.
著者らは，昨年度の論文8) においてCRD法を開水路流 れの一次元と二次元問題に適用し, 水理模型実験結果や ダム破壞流れなどの理論值と比較しその有効性を示した. しかしながら，それらの検証は比較的簡単な河道形状を 対象としており，実河川での洪水流を対象にした検証は 行っていない，そこで本論文では，水理模型実験により 詳細な水理量のデータが得られている急流都市河川の豊 平川を対象として，CRD法の適用性を調べる。 また，実 河川にCRD法を適用寸る際の境界条件や抵抗項の取り扱 いについて示す.

\section{2. 計算法}

（1） CRD法

二次元一階双曲型偏微分方程式を式(1)で表す.

$$
\frac{\partial \phi}{\partial t}+\nabla \mathbf{F}+\Omega=0
$$

ここに， $\phi$ は保存変量， F は流束である．ガウスの 発散定理を使えば, 式(1)は式(2)に書き換えられる(簡単 のため $\Omega=0$ とする).

$$
\int_{A} \frac{\partial \phi}{\partial t} d A+\Phi^{T}=0
$$




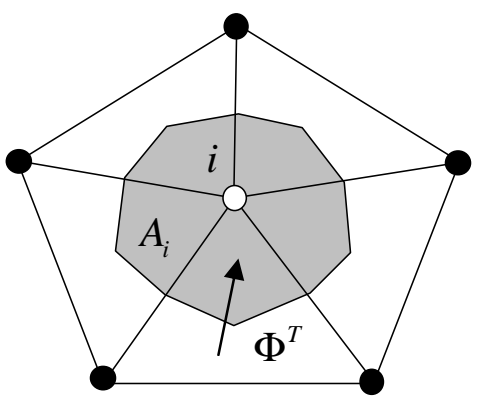

図-1ＣRD法における計算点 (三角形の頂点におく)

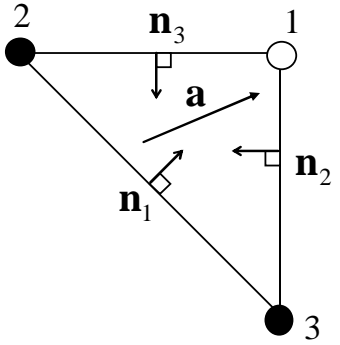

(a) 点1に配分する

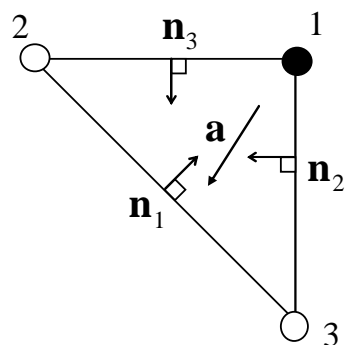

(b) 点2,3に配分する
図-2 Residualの配分法波動の伝播するaの方向に配分

$$
\Phi^{T}=\int_{T} \nabla \cdot \mathbf{F} d A=\oint_{\partial T} \mathbf{F} \cdot d \mathbf{n}
$$

ここに， $\Phi^{T}$ はResidualと呼ばれる，A は計算点の支 配面積, $\mathbf{n}$ は計算領域の境界線に外向きの垂直ベクトル, Tは計算要素（ここでは三角形）を表す． $\Phi^{T}$ を式(3)に 示寸係数 $\beta_{i}^{T}$ に応じて, 計算点 $i$ 一配分する.

$$
\phi_{i}^{n+1}=\phi_{i}^{n}-\frac{\Delta t}{A_{i}} \beta_{i}^{T} \Phi^{T}
$$

ここに, $n$ は時間ステップ, $\sum_{i} \beta_{i}^{T}=1$ である.

計算単位は, 平面二次元計算では非構造の三角形格子 を用いる．計算点は三角形の頂点（Cell-vertex）にとり

（図-1），1つの三角形格子（計算要素）ごとに独立し $\tau$ Residual $\Phi^{T}$ を計算する。

式(2)に左固有ベクトル $L$ を作用させて固有ベクトル 空間に変換し， $L \Phi^{T}$ をInflow parameter $k_{i}=\mathbf{a} \cdot \mathbf{n}_{i} / 2$ の符号が正の方向に配分する(風上スキーム).ここに,

$\mathbf{a}$ は波動の伝播速度, $\mathbf{n}_{i}$ は辺に垂直で計算要素に内向 きのベクトルである. 図-2(a)のように $k_{i}>0 か ゙ 1$ 点の場 合は点1に配分する．（b)のように2点に向かう場合には 多くの方法が提案されているが，本論文では $k_{i}$ の比に 応じて配分する(4)式の方法を用いる．得られた配分に右 固有ベクトル $R$ を作用させて元の空間に戻し, $\Delta t$ 後の 保存変量 $\phi$ を算定する. 一次元計算でも同様である.

$$
\text { LDA-scheme }^{4)}\left\{\begin{array}{l}
\beta_{2}=k_{2} /\left(k_{2}+k_{3}\right) \\
\beta_{3}=k_{3} /\left(k_{2}+k_{3}\right)
\end{array}\right.
$$

\section{（2）基礎方程式}

一次元浅水流方程式は(1)式において,

$\phi=\left(\begin{array}{l}A \\ Q\end{array}\right), \mathbf{F}=\left(\begin{array}{c}Q \\ \frac{Q^{2}}{A}+g[A] H\end{array}\right), \Omega=\left(\begin{array}{c}0 \\ f Q\end{array}\right)$

ここに, $A$ は河積, $Q$ は流量, $g$ は重力加速度, $H$ は水位, $f=g n^{2} q / h^{7 / 3}, n$ はマニングの粗度係数, $q$ は単位幅流量, $h$ は水深である. なお, []は計算要 素の平均を表し定数として扱う.

平面二次元計算の基礎方程式は,

$$
\phi=\left(\begin{array}{c}
h \\
q_{u} \\
q_{v}
\end{array}\right), \mathbf{F}=\left(\begin{array}{c}
h \mathbf{v} \\
q_{u} \mathbf{v}+g[h] H \mathbf{i} \\
q_{v} \mathbf{v}+g[h] H \mathbf{j}
\end{array}\right), \Omega=\left(\begin{array}{c}
0 \\
f q_{u} \\
f q_{v}
\end{array}\right)
$$

ここに, $\mathbf{v}=u \mathbf{i}+v \mathbf{j}, u, v$ は $x, y$ 方向の水深平均 流速, $\mathbf{i}, \mathbf{j}$ は $x, y$ 方向の単位ベクトル, $q_{u}=u h$, $q_{v}=v h$ である.

(3) Entropy Fix

一次元のCRD法では支配断面で膨張衝撃波を許すが, そのEntroy Fix として一次元河床変動計算の利用 ${ }^{8}$ を用い る. 詳細は文献8)を参照.

\section{（4）抵抗項の取り扱い}

水深がゼロに近く流速が速い場合，式(6)の抵抗項が非 物理的な值となる. したがって，水深が極端に浅くなる 計算点が発生寸る二次元計算においては, $\Delta t$ 後の保存 変量 $\phi^{n+1}$ を算出する際に式(7)に示すように抵抗項を陰 的に取り扱う。なお，一次元の場合は陽的な取り扱いで 計算が安定している.

$$
\left(\begin{array}{c}
h \\
(1+f \Delta t) q_{u} \\
(1+f \Delta t) q_{v}
\end{array}\right)^{n+1}=\left(\begin{array}{c}
h \\
q_{u} \\
q_{v}
\end{array}\right)^{n}-\frac{\Delta t}{A_{i}} \beta_{i}^{T} \Phi^{T}
$$

\section{（5）上流端条件，下流端条件}

二次元計算においては，上下流端には下流からの擾乱 が伝わらないように助走区間を設ける。上流端では勾配 が緩い貯水槽のようなものを設け，上流端の計算点で任 意の流量 $\left(q_{u}, q_{v}\right)$ を与える. 下流端の計算点では自 由水面を想定し圧力水頭をゼロとする.

一次元のCRD法については文献4)に示した.

\section{（6）壁面条件}

壁面の計算点において計算領域外一向かう流速成分が ゼロとなるように計算領域外から特性波る $\omega$ を与える.

$$
\partial \phi=R \partial \omega
$$




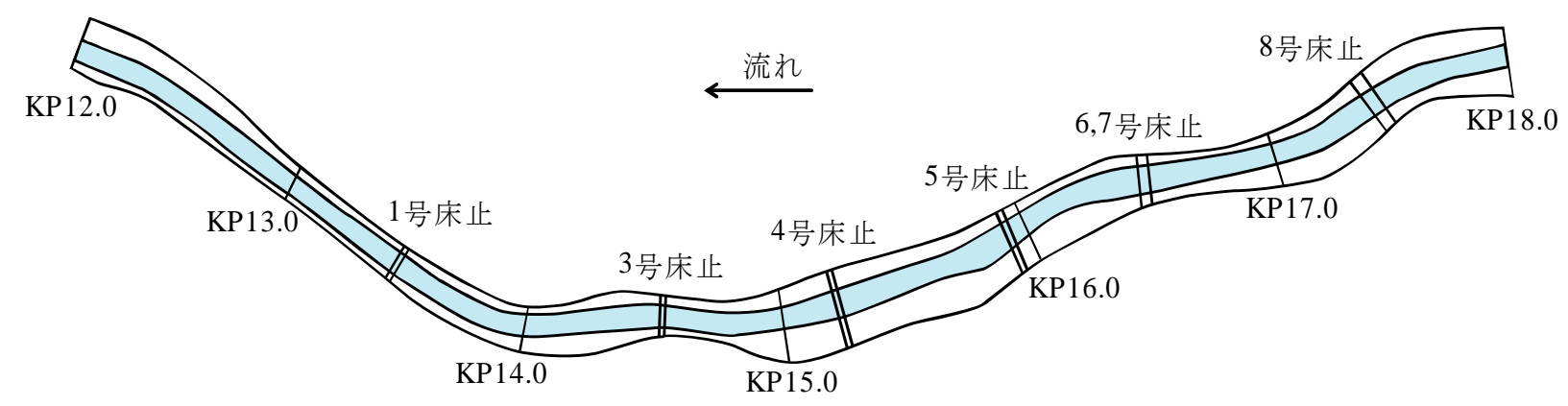

図-3 豊平川大型水理模型実験の対象位置図

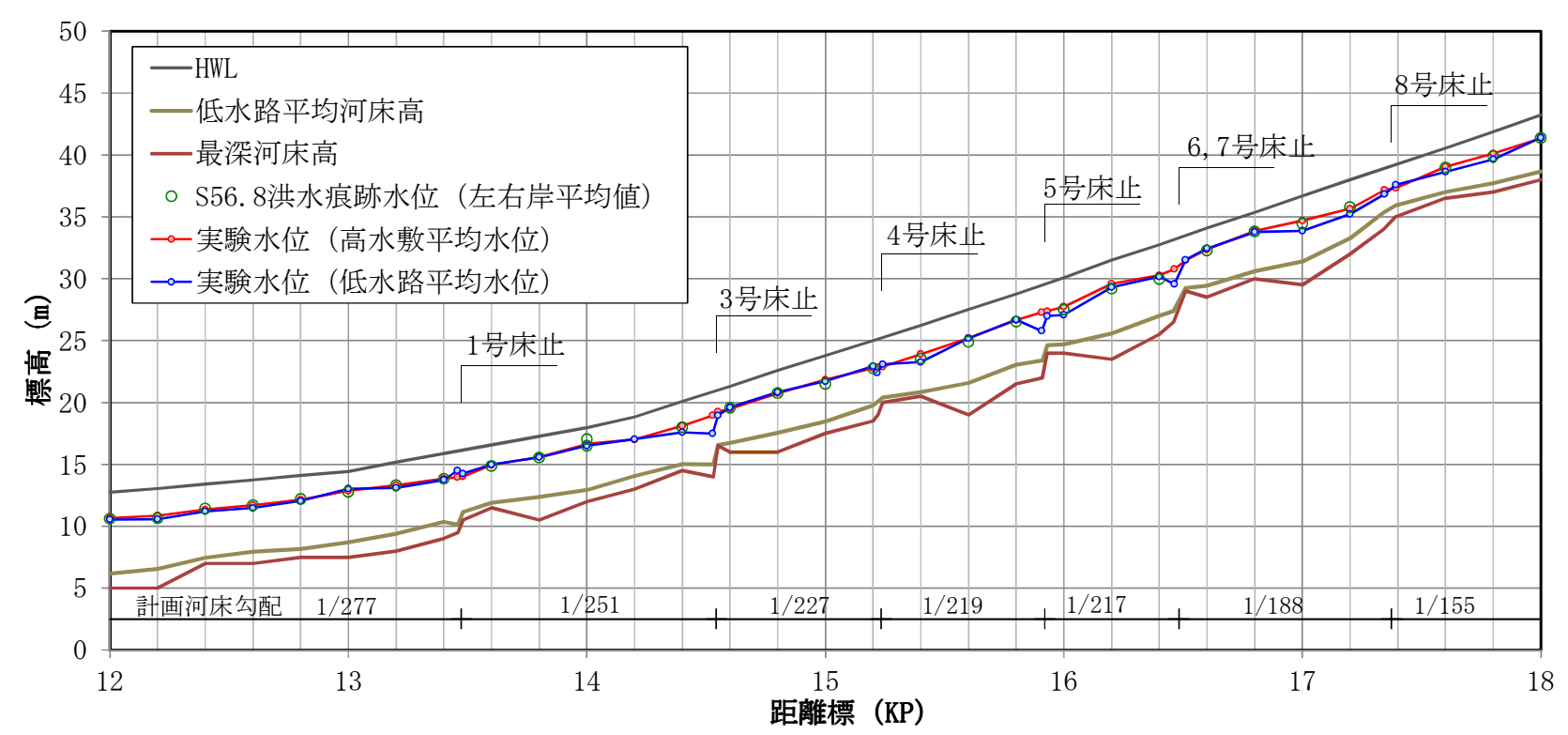

図-4 豊平川水理模型実験の河床高と実験水位縦断図

\section{3. 豊平川へのCRD法の適用}

豊平川は大都市を流れる急流河川であり，昭和56年洪 水では低水護岸や高水敷上の施設等で多数の被害が発生 した.このことから, 開発土木研究所（現 : 寒地土木研 究所）では昭和56年洪水時の洪水流下特性を確認するた め，縮尺1/50の大型水理模型実験を行っている．本論文 では，平成元年と平成2年に行った昭和56年洪水の固定 床水理模型実験 ${ }^{9}{ }^{10)}$ について，一次元と平面二次元の CRD法を用いた同様の計算を行い適用性の検討を行う. なお，河床変動計算を利用した一次元計算を1D-CRDz, 平面二次元計算を2D-CRDと記述する。計算の時間刻み にはCFL条件を用いた。

\section{（1）水理模型実験の概要}

豊平川水理模型実験の対象区間はKP12.0からKP18.0で ある（図-3）。この区間は床止めが縦断的に連続してお り，河床は1/150～1/280の急勾配である. 河道は複断面 であり，平均川幅の約 $200 \mathrm{~m}$ に対して低水路幅は約 $90 \mathrm{~m}$ と 半分程度である. 模型の河床形状は昭和56年8月洪水直 後（昭和56年9月測量）の河川横断測量結果を用いてい る. 対象流量は昭和 56 年 8 月洪水ピーク流量の $1,417 \mathrm{~m}^{3} / \mathrm{s}$,
粗度係数は洪水痕跡水位からの逆算により低水路 0.033 , 高水敷0.045を用いている.

実験結果の水位縦断図を図-4に示す（実験水位は実際 の水位に換算した值である）。実験水位と洪水痕跡水位 と比較するとKP14.0を除いてほぼ一致している. 3号床 止，5号床止，6,7号床止の下流では，低水路河床高の落 差により局所的に跳水が発生しているが，高水敷の水位 が高いために低水路と高水敷では水位差が発生している.

\section{（2）計算条件}

\section{a) 一次元計算}

実験結果から昭和56年8月洪水では流量の約 $90 \%$ が低 水路部分を流れたと言われている.このため一次元計算 は，低水路の河積のみで計算した場合（単断面）と合成 粗度を用いて河道全体で計算した場合（複断面）の2 ケースの計算を行い，低水路と高水敷の分担流量を推定 する. 河道断面は実験に用いた昭和56年9月測量（床止 箇所以外は $\Delta x=200 \mathrm{~m} ）$ を用い，上流から $1,417 \mathrm{~m}^{3} / \mathrm{s}$ の一 定流量を与え定常となるまで計算を行った。下流端水位 はKP12.0の痕跡水位 $10.790 \mathrm{~m}$ と, 粗度係数は模型実験 条件と同様とした.

\section{b) 平面二次元計算}

平面二次元計算の計算格子は，一辺が $10 \mathrm{~m}$ 程度の三角 


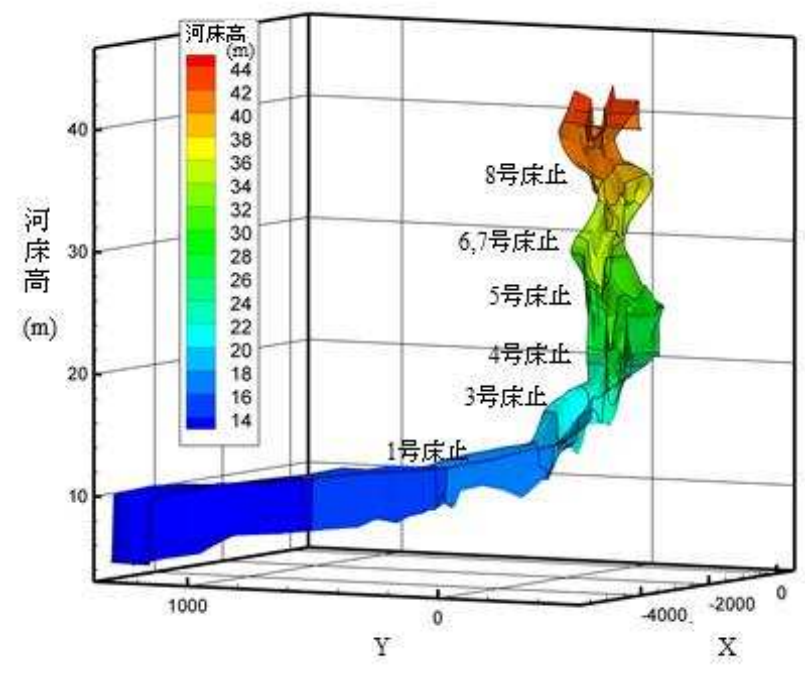

図-5＼cjkstart河床高コンター図 (2D-CRD)

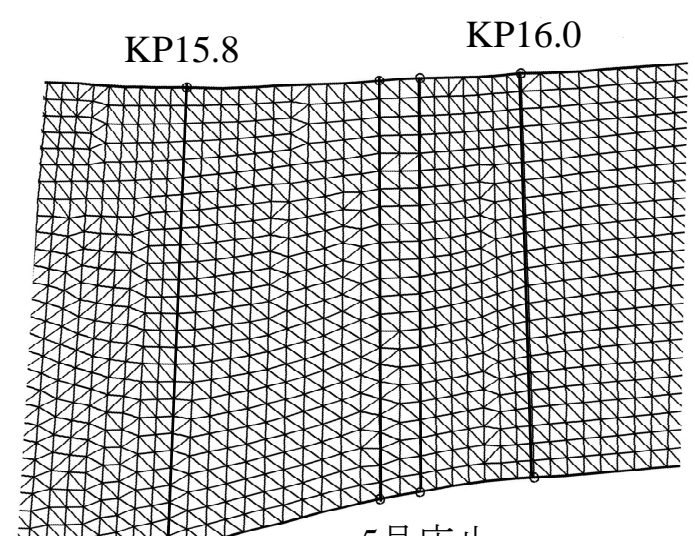

5 号床止

$\leftarrow$ 流れ

図-6２D-CRDIたけるメッシュ図（一部抜粋）

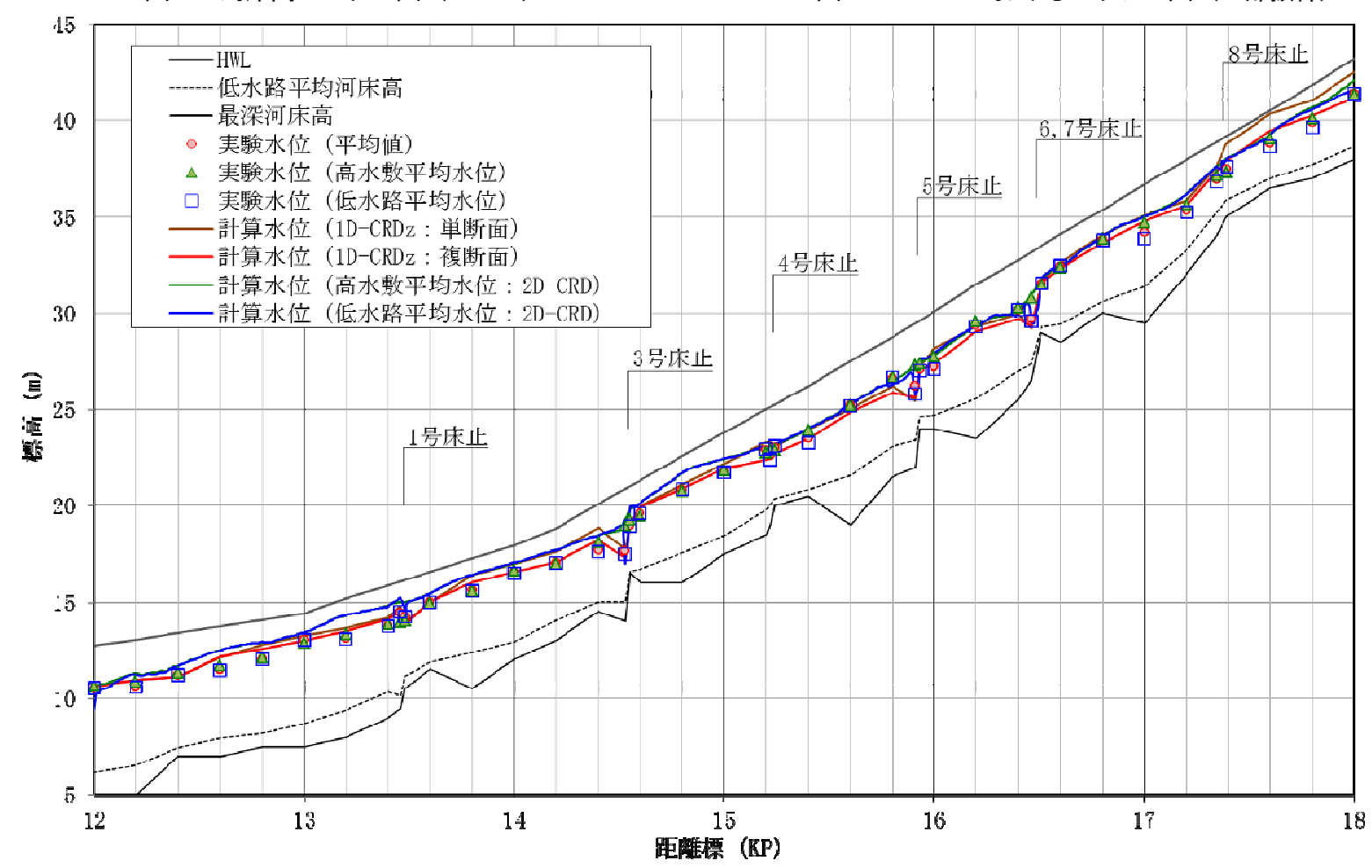

図-7 計算水位縱断図

形格子とし（図-5, 図-6），計算流量と粗度係数は比較 のため模型実験と同様とした.

\section{（3）計算結果と実験値の比較}

\section{a) 計算水位}

水位縦断の計算結果を図-7に示寸。1D-CRDz（複断 面）では，5号床止と6号床止下流の跳水部でやや実験值 に比べて低くなったが，全川的に実験值を良好に再現し ている. この跳水部の水位差は高水敷と低水路の流れの 干渉の影響が含まれていないためと考えられる。1D$\mathrm{CRDz}$ (単断面) は, $1 \mathrm{D}-\mathrm{CRDz}$ (複断面) と比較して平 均 $0.3 \mathrm{~m}$ 程度の高い水位となった。 この差は高水敷の流量 の分担によるが，その流量を平均川幅と平均流速（約 $200 \mathrm{~m} \times$ 約 $4.0 \mathrm{~m} / \mathrm{s}$ ） から試算すると，17\%程度の分担流量
があると推定される。なお，8号床止上流は1D-CRDz （単断面）の水位が高くなっているが，この区間は高水 敷の分担流量が大きいと考えられる.

2D-CRDの水位は断面平均值である.4号床止より下流 において実験值よりやや高いが，4号床止上流では良く 一致している. 5 号床止，6,7号床止下流では高水敷平均 水位と低水路平均水位の差が生じているが，計算結果も その特徴を捉えており適合性は良い. なお，4号床止下 流で水位が全体的にやや高くなっていることについては, 今後詳細に確認が必要と考えられる.

\section{b) フルード数}

フルード数の計算結果を図-8に示寸. 2D-CRDのフ ルード数は断面平均值である。1D-CRDz（単断面）, 1D-CRDz（複断面），2D-CRDともに3号床止，5号床止， 


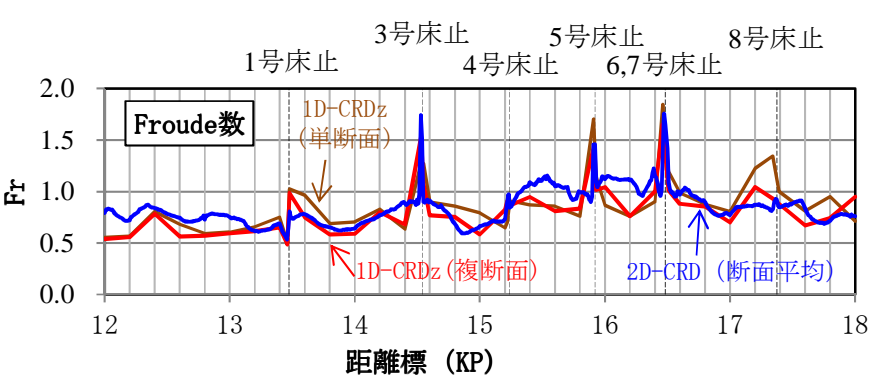

図-8 Froude数縱断図

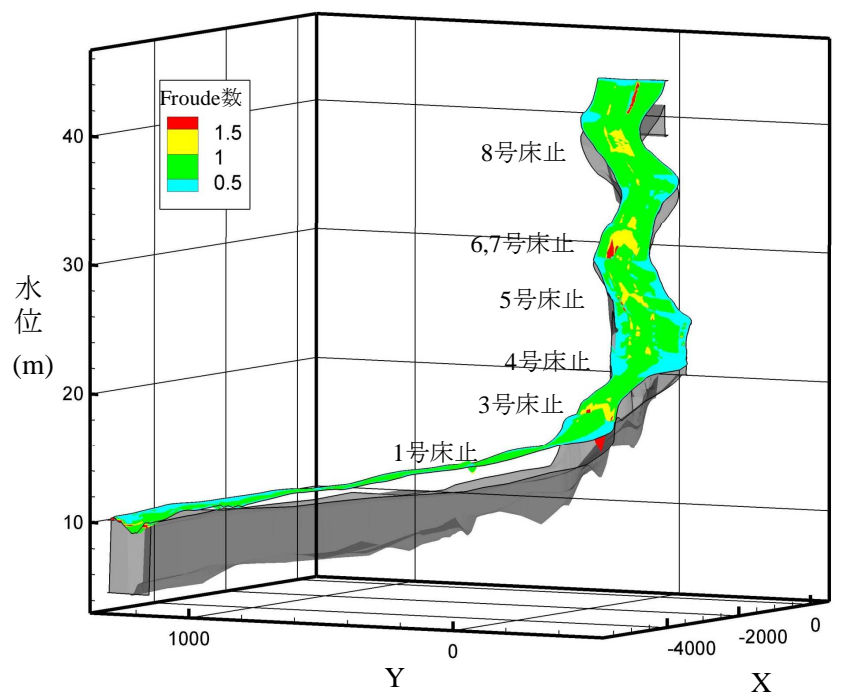

図-9 Froude数分布図 (2D-CRD)

6,7 号床止下流でフルード数がいずれも 1.7 程度となり概 ね一致している. 2D-CRDのフルード数の平面分布を図 -9 に示寸. 全川的にはフルード数 1.0 以下の常流で流れ るが，床止周辺部（主に低水路）で射流が発生している。

c）低水路と高水敷の分担流量

図-10は，低水路と高水敷の分担流量の2D-CRD と実験 結果との比較である. 8号床止上流では計算值と実験值 に乘離が見られるが，これは上流端の境界条件の違いに よると考えられる.KP17.2より下流区間で比較を行った 実験值では低水路の分担流量が95\%程度となっているが, 計算值は約 $87 \%$ とやや小さい. しかし, 上記a)の1DCRDzの結果とは近い值となっている. 図-11は計算值と 実験值の流速を比較したものであるが，高水敷の流速は 概ね一致している. このことから, 分担流量の計算值と 実験值の乘離は, 実験の低水路流速がやや大きく測定さ れたためと考えられる.

\section{d）床止周辺の流れ}

落差の大きい5号床止，6,7号床止に着目して，2DCRDの流れの適用性を確認した（図-12）.

計算水位のコンター図ではいずれの床止においても床 止下流の低水路で水位低下が生じている. このため, 流 速ベクトル図に示寸ように，高水敷から低水路一流入す る流れ（落ち込み流）が発生している。.また，床止下流 から $200 \mathrm{~m}$ 程度下流では逆に低水路から高水敷への乗り 上げが生じている.これらの流向は実験においても確認 されていて，流れの特徵を良く捉えている．床止下流の

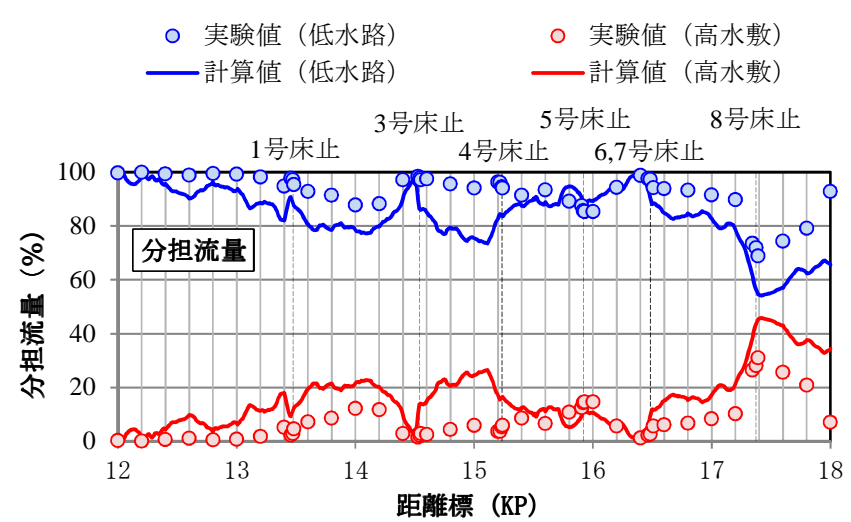

図-10２D-CRDににおける低水路と高水敷の分担流量

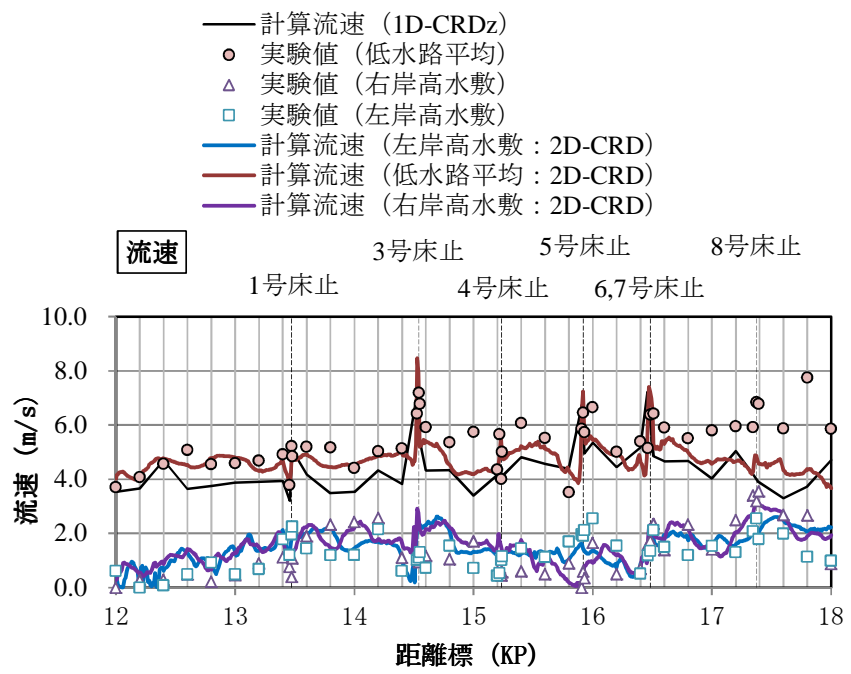

図-11 流速縱断図

高水敷と低水路の横断水位差（5号床止で約 $2.5 \mathrm{~m} ， 6$ 号床 止で約 $1.5 \mathrm{~m})$ についても同様に，その值と形状において 計算と実験は概数一致している.

\section{4. おわりに}

本論文では，不連続解を持つ流れの多次元解析法とし て開発されたCRD法を急流都市河川の豊平川に適用し， 実河川・実スケールでの適用性について検討した。

一次元計算では, 複断面の合成粗度を用いた単断面的 な計算法においても実験水位をよく表していた。ただし， 床止下流の跳水部における水位がやや低くなる傾向がみ られた. 平面二次元計算では, 床止下流における高水敷 から低水路への落ち込み流や乗り上げについて, 実験結 果の流れの特徴を表しており，床止下流の横断水位も実 験值とよく適合していた.

このことから, 急勾配で緹断的に床止が連続する複雑 な流れにおいても，CRD法を用いた一次元，平面二次元 の計算の適合性は良く，充分，実用に適した計算法であ ると考えている.

謝辞 : 本研究では，株式会社水工リサ一チの工藤久良， 岡田操，加藤一夫，小川芳樹各位に豊平川水理模型実験 のデータを整理して頂いた。ここに記して感謝の意を表 します。 

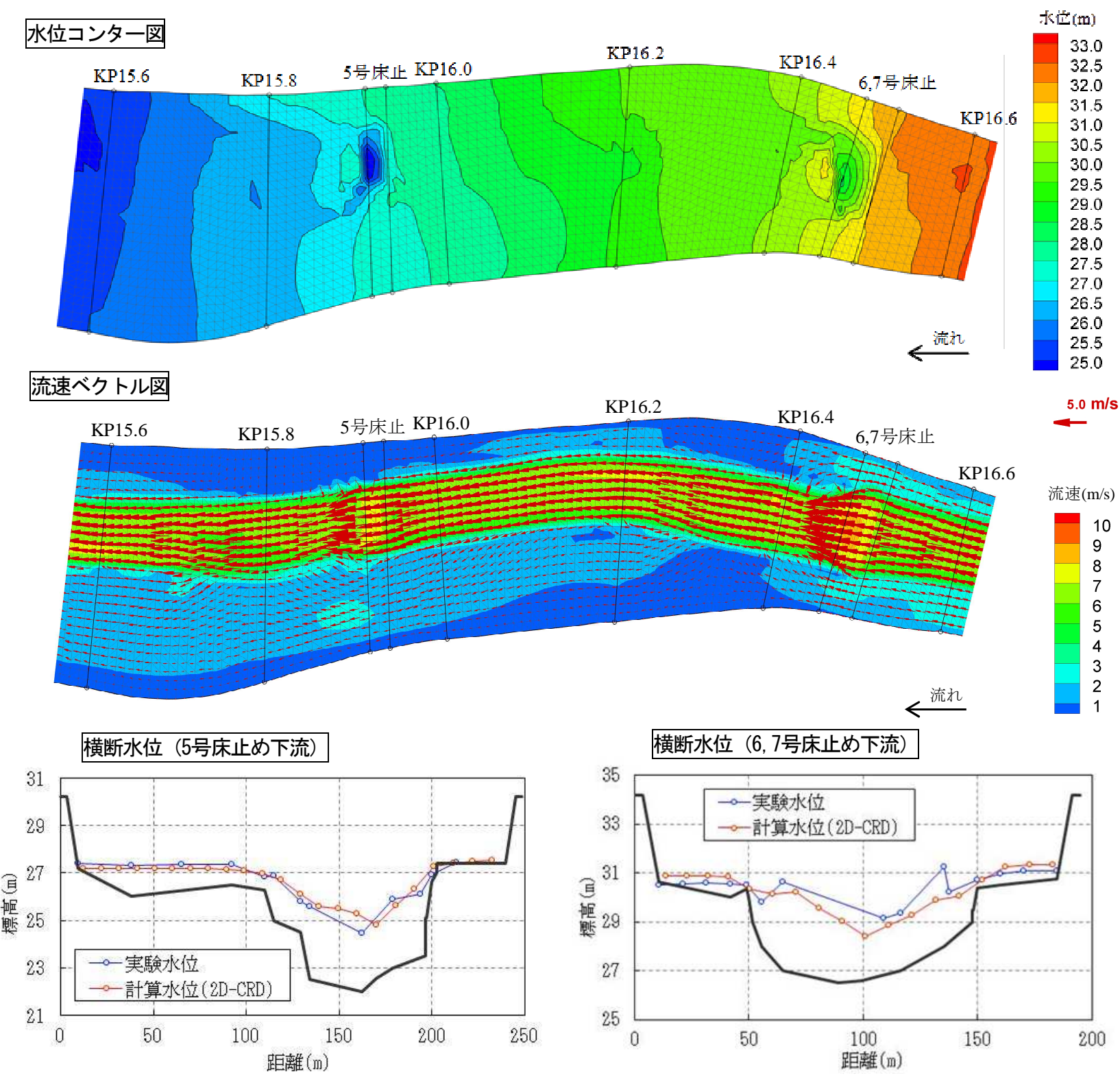

図-12 5号床止 6, 7号床止周辺の計算結果

\section{参考文献}

1) 山海堂, 改定護岸の力学的設計法, 国土技術研究センタ一編, 2007.

2) 例えば崇田徳彦, 清水康行, 渡邊康玄: MacCormack法を用い た常・射流計算, 北海道開発局開発土木研究所月報, No.448, pp.23-32, 1990.

3) 清水康行, 藤田睦博, 平野道夫: 連続床止め工を有する複断 面河道における流れと河床変動の計算, 水工学論文集, 第43 巻, pp.683-688, 1999.

4) H.Paillere, and H.Deconinck.: Compact Cell Vertex Schemes on Unstructured Meshes. In "Euler and Navier-Stokes Solvers Using Multi-Dimensional Upwind Schemes and Multigrid Acceleration" Edited by Herman Deconinck and Barry Koren, Vieweg, 1997

5) 西本直史, 森明巨, 板倉忠興, 金澤克己: FDS法による1次元開 水路流れの数值解析, 土木学会論文集, No.670/II-54, pp.25-36, 2001.
6) 秋山壽一郎, 重枝末玲, 鬼束幸樹, 白川寛樹: 平面 2 次元数值 モデルによる急流都市河川の流況解析, 水工学論文集, 第48 巻, pp.631-636, 2004.

7) Arpad Csik., Mario Ricchiuto, and Herman Deconinck.: A Conservative Formulation of the Multidimensional Upwind Residual Distribution Schemes for General Nonlinear Conservation Laws, Journal of Computational Physics, 179, pp.286-312, 2002.

8) 堀江克也, 岡村誠司, 小林雄介, 兵藤誠, 樋田祥久, 西本直史, 森明巨: CRD法を用いた常流・射流混在流れの数值解析, 水 工学論文集, 第55巻, pp.1189-1194, 2011.

9) 北海道開発局開発土木研究所, 財団法人河川環境管理財団: 平成元年度豊平川大型水理模型実験業務報告書, 1989 .

10) 北海道開発局開発土木研究所, 財団法人河川環境管理財団: 平成2年度豊平川大型水理模型実験業務報告書, 1990 .

(2011. 9. 30受付) 